\section{USUÁRIO OU TRAFICANTE? APONTAMENTOS SOBRE A APLICAÇÃO DA LEI DE DROGAS NO MUNICÍPIO DE PONTES E LACERDA/MT}

\author{
USER OR TRAFFICKER? NOTES ON THE APPLICATION \\ OF THE DRUG LAW IN THE MUNICIPALITY OF PONTES \\ E LACERDA / MT
}

\author{
Alex Penazzo Tavares ${ }^{1}$ \\ Fernando Vechi ${ }^{2}$ \\ Emillyane Cristine Silva Adorno ${ }^{3}$
}

\title{
RESUMO
}

O presente artigo visa apresentar os desdobramentos da aplicação da Lei 11.343/2006, a Lei de Drogas, na cidade de Pontes e Lacerda, no estado de Mato Grosso. A hipótese do estudo é que, diante da subjetividade presente na Lei de Drogas no tocante ao tratamento de usuários e traficantes, as pessoas que são autuadas em flagrante por tráfico em Pontes e Lacerda/MTestariam com pequena quantidade e mesmo assim seriam consideradas traficantes, seguindo uma lógica de seletividade nacional. Possuindo caráter quantitativo e bibliográfico, foi utilizado como principal instrumento a pesquisa documental, onde foram analisados procedimentos policiais da Delegacia de Polícia de Pontes e Lacerda do mês de maio de 2019 a fim de verificar a ocorrência da hipótese, bem como, traçar o perfil das pessoas autuadas, analisando, para tanto, quatro variáveis: social, econômica, racial e de gênero. Com os resultados obtidos, os dados colhidos apontam que a hipótese é confirmada na realidade de Pontes e Lacerda/MT e indica que a maioria das pessoas autuadas foram homens (76\%); a maioria das pessoas são pardas; o maior número de pessoas jovens entre 18 e 29 anos de idade; possuindo, na maioria das vezes, renda de um até três salários mínimos; toda as autuações ocorreram em flagrante de delito; a polícia que mais realizou apreensões foi a Polícia Judiciária Civil. Desta forma, o estudo indica que existe seletividade quanto a aplicação da Lei de Drogas no município, apontando que a atual política criminal proibicionista necessita ser repensada.

PALAVRAS-CHAVE: Lei de Drogas. Pontes e Lacerda. Proibicionismo. Tráfico de Drogas.

\footnotetext{
1 Discente do curso de Direito da Universidade do Estado de Mato Grosso, campus Pontes e Lacerda. E-mail: penazzo56@gmail.com. ORCID 0000-0003-4428-8678

2 Doutorando em Ciências Criminais pela Pontifícia Universidade Católica do Rio Grande do Sul. Mestre em Ciências Criminais pela Pontifícia Universidade Católica do Rio Grande do Sul. Docente do curso de Direito da Universidade do Estado de Mato Grosso, campus Pontes e Lacerda. E-mail: profvechi@gmail.com. ORCID 0000-0003-0670-3404

${ }^{3}$ Discente do curso de Direito da Universidade do Estado de Mato Grosso, campus Pontes e Lacerda. E-mail: aemillyane@gmail.com. ORCID 0000-0003-3118-8512
} 
DOI 10.20873/uft.2359-0106.2021.v8n2.p526-556

\begin{abstract}
This article aims to present the consequences of the application of Law 11.343/2006, the Drug Law, in the city of Pontes e Lacerda, in the state of Mato Grosso. The hypothesis of the study is that, given the subjectivity present in the Drug Law regarding the treatment of drug users and dealers, people charged with drug trafficking in Pontes and Lacerda/MT had a small amount of drugs and that the apprehensions are carried out, mostly in the act. Having quali-quantitative character, documentary research was used as the main instrument, where police procedures of the Pontes e Lacerda Police Station of May 2019 were analyzed in order to verify the occurrence of the hypothesis, as well as to outline the profile of the assessed people, analyzing four variables: social, economic, racial and gender. With the results obtained, the data collected indicate that the hypothesis is confirmed in the reality of Pontes and Lacerda/MT and indicates that the majority of the people assessed were men (76\%); most people are brown; the largest number of young people between 18 and 29 years of age; having, in most cases, an income of one to three minimum wages; all assessments occurred in the act of committing an offense; and the police that most carried out apprehensions was the Civil Judicial Police. Thus, the study indicates that there is selectivity regarding the application of the Drug Law in the municipality, pointing out that the current prohibitionist criminal policy needs to be rethought.
\end{abstract}

KEYWORDS: Drug Law. Pontes and Lacerda. Prohibitionism. Drug trafficking.

\title{
1. INTRODUÇÃO
}

O presente artigo é fruto de inquietações acerca da Lei de Drogas vigente e as características presentes no município de Pontes e Lacerda, estado de Mato Grosso, enquanto cidade que está na faixa de fronteira com a Bolívia, conhecida pela presença de atividades de mineração e também pelo fluxo de drogas.

As drogas estão fortemente presentes na vida cotidiana e são utilizadas por toda humanidade. Utilizam-se drogas para aliviar dores, para estimular o corpo e a mente, para acalmar, para fugir da realidade, enfim para uma infinidade de situações. Ocorre que, determinadas drogas são criminalizadas, as chamadas substâncias ilícitas, e por este motivo não podem ser utilizadas livremente.

Os primeiros pontos controversos das drogas residem na definição do que é droga e o motivo pelo qual determinadas drogas são consideradas ilícitas ${ }^{4}$. No decorrer deste estudo, será realizado apontamentos para clarear a discussão e inserir ao tema central.

A Lei 11.343/2006 deixa uma marca subjetiva no que tange a consideração de usuário e traficante, abrindo margem para discricionariedade. Esta perguntaproblema guia pesquisa: como é aplicação da Lei de Drogas no âmbito policial na

\footnotetext{
${ }^{4}$ Ver tópico 3
} 
ISSN n 2359-0106

Vol. 8, n. 2, 2021.

DOI 10.20873/uft.2359-0106.2021.v8n2.p526-556

cidade de Pontes e Lacerda?

A questão criminal, especificamente relativa às drogas, envolve discussões em diversos campos do conhecimento, característica essa também do campo criminológico. O marco teórico utilizado na presente pesquisa foi a criminologia crítica, por entender que é a partir do paradigma do conflito que existe o real entendimento sobre o funcionamento do sistema de justiça criminal, colocando em questionamento a criminalização de determinadas condutas e o status quo do Direito Penal.

A pesquisa foi estruturada em dois tópicos. No primeiro tópico é realizada a contextualização do proibicionismo e como se desenvolve enquanto política criminal, buscando definições e apresentando a sanha probicionista enquanto uma escolha política.

No segundo tópico, além da descrição dos dados obtidos a campo por meio da análise de procedimentos policiais, corporificando o debate por meio da análise analítica, é apresentada a metodologia utilizada para o desenvolvimento, o motivo pela escolha da temática e as peculiaridades em torno da cidade de Pontes e Lacerda/MT e a relação com as substâncias consideradas ilícitas. Por fim, é realizada uma exposição final relacionando os achados com os paradigmas criminológicos.

\section{DO PROBICIONISMO COMO POLÍTICA CRIMINAL À GUERRA ÀS DROGAS}

\subsection{O PROIBICIONISMO COMO POLÍTICA CRIMINAL}

Neste primeiro momento será realizada a conceituação e a correlação de proibicionismo e de política criminal. Partindo, para tanto, das seguintes indagações: o que é política criminal? o que é o proibicionismo? e por que o proibicionismo é uma política criminal?

A utilização de mecanismos de controle sociais, quando assim convencionados pelo contrato social ${ }^{5}$, possibilita regular a sociedade sem necessitar

5 O conceito de contrato social é trazido por Rousseau (2011), onde, segundo o autor, cada pessoa faz a alienação de todos os seus direitos em favor de toda a comunidade "(...) dando-se cada um por inteiro, para todos é igual condição,_e, sendo_ela para todos igual, ninguém se interessa_em torná-la 
DOI 10.20873/uft.2359-0106.2021.v8n2.p526-556

de profundos debates. No sistema brasileiro onde os poderes que formam a república possuem, formalmente, atuações delimitadas pela Constituição Federal de 1988, cabe ao poder legislativo criar as normas que regulam a vida em sociedade. $\mathrm{E}$ é no legislativo que a política criminal possui uma face mais visível, não sendo uma exclusividade nesse campo.

No século XVIII a escola clássica representada por Cesare Beccaria em Dos Delitos e das Penas (1774) trouxe a ideia de que os legisladores deveriam possuir apreço pela política criminal no controle do desvio:

É melhor prevenir os crimes do que ter de puni-los; e todo legislador sábio deve procurar antes impedir o mal do que repará-lo, pois uma boa legislação não é senão a arte de proporcionar aos homens o maior bemestar possível e preservá-los de todos os sofrimentos que se lhes possam causar, segundo o cálculo dos bens e dos males desta vida (BECCARIA, 1764, p. 67)

$\mathrm{Na}$ abordagem de Beccaria - e da escola clássica ${ }^{6}$ como um todo - a lei pura e simples exercia um papel de prevenção ao cometimento de crimes. Um dos principais indicativos de que o legislador, diante de sua incumbência, deveria ter um olhar específico na criação de normas penais, a fim de preservar o bem-estar social, prevenindo o delito por meio de leis.

A forma de condicionar o legislador a ter atenção especial para essa questão, nos mostra uma das faces do que é conhecido como política criminal. Aponta-se que, apesar do diálogo com os demais campos do conhecimento, até porque tratase de um fenômeno social, a política criminal está mais inclinada à ciência política.

A pena, entendida como o fim do direito penal, momento no qual o Estado manifesta o poder de punir, deve receber o amparo quanto a sua existência e também em sua manifestação. Neste sentido,

aos outros onerosa" (p. 25). Desta forma, por meio do contrato social, a liberdade individual é garantida e, ao mesmo tempo, haveria segurança e o bem-estar destas pessoas. No estado de natureza, chamado pelo autor de primitivo, a espécie humana pereceria, pois não haveria soma de forças e, consequentemente, não haveria proteção dessas pessoas.

${ }^{6}$ A escola clássica entendia o direito penal e a pena como instrumento para defender a sociedade do crime e a violação constituiria a quebra do pacto social. Na visão da escola clássica, isso criaria um efeito dissuasivo no cometimento de delitos, ou seja, seria uma contramotivação do crime (BARATTA, 2002). 
A política criminal vem a ser a sciencia chamada a apreciar o direito existente sob o ponto de vista da sua correlação com o fim do direito penal a repressão do crime, e a indicar, d'entre os meios disponíveis, os mais adequados para a consecução desse fim (sic) (VON LISZT, 1899, p. 36).

Pode-se dizer que um dos encargos da política criminal é oferecer critérios para que o valor do direito penal alcance o seu fim (pena).

Não é possível trazer um conceito unívoco de política criminal. Na tentativa de conceituar o termo, Von Liszt apud Carvalho (1996, p. 17), diz que política criminal é um Contenido sistemático de princípios - garantidos por la investigación científica de las causas del delito y de la eficácia de la pena según los cuales el Estado dirige la lucha contra el delito, por medio de la pena y de sus formas de ejecución. Deste conceito é possível extrair informações relevantes acerca do tema, principalmente porque demonstra que a política criminal está subsidiada pela investigação científica das causas do delito e a eficácia da pena.

Assim, no plano formal, se a política criminal operacionaliza as causas do delito e da eficácia da pena, o seu campo de atuação está delimitado no percorrer do processo de criminalização de condutas, ou seja, criação de normas reguladoras, até a aplicação e efeitos da punição estatal.

Apesar da divergência existente quanto ao conceito de política criminal, é possível dizer que esta exerce "a função de estabelecer como devem ser configuradas a legislação e a jurisprudência, para prover uma proteção mais eficaz da sociedade" (ZAFFARONI; BATISTA, 2003, p. 274). Isto é, no propósito trazido por Von Liszt, a Política Criminal será o ponto norteador para o legislador e o órgão julgador enfrentarem a questão criminal, mas a política criminal não está limitada nestes termos. Nos dias atuais, a política criminal é considerada um saber importante para além dos legisladores, devendo ser inserida no direito penal ${ }^{7}$ (ZAFFARONI; BATISTA, 2003).

Na visão dos autores, "a política criminal é resultante da interdisciplinaridade do direito penal com a ciência política e especialmente com a engenharia

\footnotetext{
7 Zaffaroni e Batista (2017) explicam que a política criminal, diferente da criminologia e da penologia, não deve confrontar o direito penal - portanto, não impor limites - por não se tratar de um saber empírico.
} 
DOI 10.20873/uft.2359-0106.2021.v8n2.p526-556

institucional" (ZAFFARONI; BATISTA, 2003, p. 275), assim, estando a política criminal intrinsecamente ligada à ciência política, o conceito de política criminal abrangeria a política de segurança pública, a política judiciária e a política penitenciária (MALAGUTI, 2011).

Diante disso, a política criminal exerce papel fundamental,

En la sociedad democrática contemporánea la política criminal está circunscrita a la racionalización de las políticas públicas. Es decir, que es el Estado y no una individualidad, grupo o parcialidad política quien define que es delito y como se sanciona. Por esta razón se dice el Estado puede y debe orientarse hacia el ideal de la justicia y no a la venganza o revancha social (GUARTÁN; MERCHAN, 2017, p. 55)

Reside na política criminal um mecanismo importante para que o Estado exerça o jus puniendi e, como supramencionado, exerça de forma isonômica este poder. Todavia, por se tratar de questões políticas, esse poder pode sofrer alterações em sua intensidade de manifestação a depender dos interesses que estão camuflados (ou não) em sua criação e tratando-se de questões penais algum lado da balança pode estar mais pesado que o outro.

Realizada a conceituação de política criminal, o próximo objetivo é trazer a concepção do que é proibicionismo. Karam (2010, p. 1) assim o define:

\begin{abstract}
O proibicionismo, em uma primeira aproximação, pode ser entendido, como um posicionamento ideológico, de fundo moral, que se traduz em ações políticas voltadas para a regulação de fenômenos, comportamentos ou produtos vistos como negativos, através de proibições estabelecidas notadamente com a intervenção do sistema penal - e, assim, com a criminalização de condutas através da edição de leis penais -, sem deixar espaço para as escolhas individuais, para o âmbito de liberdade de cada um, ainda quando os comportamentos regulados não impliquem em um dano ou em um perigo concreto de dano para terceiros.
\end{abstract}

No proibicionismo o Estado direciona ações para o combate a determinadas substâncias que circulam (e sempre circularam) no meio social. Trata-se de um modelo que possui fundamento jurídico-moral (KARAM, 2010; BOITEUX, 2006) onde as substâncias rotuladas como ilícitas são escolhidas, tendo como pano de fundo o discurso de proteção da saúde pública e de endurecimento da punição. O modelo proibicionista é antagônico ao liberalismo que existia até o início do século XX e se caracteriza pelo controle da oferta, da produção e do consumo, restringindo 
o uso de determinadas substâncias através da punição estatal (BOITEUX, 2006).

Em linhas gerais, o proibicionismo relativo às drogas corresponde a restrição de consumo e/ou mercantilização de determinadas substâncias. Por não se tratar da abordagem deste estudo, não será realizada a contextualização histórica do proibicionismo, todavia será realizada uma breve menção ao surgimento do proibicionismo nos Estados Unidos, local onde o movimento foi encabeçado e se espalhou para outros países.

Quando os EUA, no século XX, arquitetaram a propaganda proibicionista e a difundiram para o resto do mundo, vários interesses os acompanhavam

não se "explica" o empreendimento proibicionista por uma única motivação histórica. Sua realização se deu numa conjunção de fatores, que incluem a radicalização política do puritanismo norte-americano, o interesse da nascente indústria médico-farmacêutica pela monopolização da produção de drogas, os novos conflitos geopolíticos do século XX e o clamor das elites assustadas com a desordem urbana (FIORE, 2012, p. 9)

As ideias proibicionistas foram a todo vapor tomando conta de países, foi o American Way of Life sendo exportado como ainda não visto antes para várias regiões do mundo (VECHI, 2016). A avalanche proibicionista tomou o globo e em 1945 com o advento da Organização das Nações Unidas ${ }^{8}$, um controle internacional de drogas começaria a viger perpetuando até os dias atuais.

Os proibicionistas se revestiram de uma cortina fina e transparente, mas que Ihe parecem espessa, de boa-fé, objetivando a difusão da proibição de substâncias, livrando o mundo do perigo das drogas, que na maioria das vezes são oriundas da própria natureza e controlando as liberdades individuais. A alcunha proibicionista não é bem recepcionada pelos próprios proibicionistas, explica-se:

Os proibicionistas nunca admitem que são, de fato, proibicionistas, na medida em que proibição é uma palavra que 'não soa bem'; é uma qualificação percebida como desagradável ou desajustada ou preconceituosa, atribuída com motivações políticas (e com razão) por quem sustenta outras visões sobre tais fenômenos (PERDUCA, 2005, p. 51)

\footnotetext{
${ }^{8}$ No caminho, a integração entre os países a fim de tratar do tema foi aumentando exponencialmente. Para tanto destaca-se a Convenção Internacional do Ópio (1912), a Conferência de Haia, a Conferência sobre a Limitação da Manufatura de Drogas Narcóticas e a $2^{\underline{a}}$ Convenção de Genebra (VECHI,2016).
} 
A lição de Perduca (2005) demonstra que o proibicionismo está intimamente ligado à moral mais que a própria sustentação científica.

Diante dos elementos acima expostos e realizando uma lacônica interpretação, nasce o que é chamado de guerra às drogas: o proibicionismo como uma política criminal. Se a política criminal orienta o Estado a tutelar determinadas ações humanas e as drogas são vistas como uma questão em que o Estado deve se ocupar e até mesmo punir, evidentemente o proibicionismo é uma política criminal.

A política criminal do proibicionismo, tratando-se de uma forma de gerir a questão das drogas de maneira restritiva, contribuiu para o vertiginoso aumento número de pessoas encarceradas no Brasil e demais países que adotaram esse modelo de tratamento das drogas (BOITEUX, 2006; BORGES, 2018; VALOIS, 2017). Como é uma política que possui fundo jurídico-moral a sua recepção em países conservadores ratifica e impulsiona a proibição, proporcionando aos traficantes a aferição de lucros exorbitantes ${ }^{9}$.

Nesse diapasão, importante sublinhar, para que o proibicionismo se estabeleça da forma como faz a gerência das drogas, é preciso que os indivíduos que compõem a sociedade, chancelem a ideia da restrição às drogas. A guerra às drogas, assim como a ideia da punição em forma de prisão, possui como característica basilar a ideia da naturalização. O processo de naturalização de determinadas questões atinentes ao crime, colocando a punição e o encarceramento como formas primárias de lidar com o desvio, resulta em uma resposta inversa daquilo para que se propõe inicialmente. Foucault (2014) em Vigiar e Punir, para além da abordagem sócio-histórica dos métodos punitivos, deixa claro que a prisão surgiu em data certa, diferente daquilo que o processo de naturalização faz crer.

${ }^{9} \mathrm{O}$ tráfico de substâncias ilícitas é considerada a segunda principal atividade comercial do planeta, ficando atrás somente dos recursos que movimentam a indústria de armas (MACRAE, 1997). "Na primeira década do milênio o narcotráfico movimentou cerca de 900 bilhões de dólares ao ano, segundo o Escritório das Nações Unidas sobre Drogas e Crime (UNODC). A cifra é equivalente a $35 \%$ do Produto Interno Bruto (PIB) brasileiro ou a 1,5\% de toda a riqueza produzida no globo" (SÃO PAULO, 2016, p. 33). 


\subsection{O PROJETO POLÍTICO DE COMBATE ÀS DROGAS}

Em muitos estudos, objetivando localizar o leitor dentro do espectro normativo, faz-se uma análise acerca das legislações brasileiras que versaram sobre drogas no país, apontando a letra fria da lei que trataram do tema. Espera-se, com este tópico, entender uma norma para além dela, ou seja, entender que a existência de interesses, sejam eles das mais diversas ordens, na criação de uma norma reguladora da vida em sociedade, especificamente no que tange às drogas $^{10}$.

Como já mencionado alhures, a criminalização de determinadas substâncias, orientada pela política criminal do proibicionismo, se apresentou em um dado momento na sociedade e se perpetua até a atualidade. Essa política não é constante como parece ser, apontando a existência de valores e vontades puramente políticas na tomada de decisão quanto a proibição de uma ou outra substância,

A maioria das substâncias hoje proibidas ao consumo já foram usadas livremente, tendo sido proibidas a partir de um determinado momento, ao mesmo tempo em que substâncias hoje livremente consumidas já foram objetos de proibições anteriores (ex. álcool e tabaco), mas não mais são submetidas a tal modelo (BOITEUX, 2006, p. 46)

Boiteux (2006), sobre esse processo de escolha política quanto a criminalização de determinadas substâncias, exemplifica a questão por meio da Lei Seca nos Estados Unidos, onde o álcool foi proibido por um determinado período, mas que não surtiu efeitos esperados, resultando como um fomento ao crime organizado no contrabando e, a contrario sensu, elevou o consumo de álcool no país.

Para MacRae (1997, p. 109) a concepção de drogas ilícitas é uma categoria "arbitrária, de natureza exclusivamente política, sem nenhum embasamento científico" e exemplifica a questão utilizando o café, bastante presente na sociedade brasileira, que já foi proibido na Europa, principalmente nas regiões protestantes do

\footnotetext{
10 Valois (2017) explica que discorrer pura e simplesmente sobre a legislação é apenas uma doutrina para aquele que recebe as informações, segundo o autor é preciso "demonstrar o lado humano, carregado de preconceitos, interesses pessoais e econômicos, existentes atrás de cada norma jurídica" (p. 323).
} 
século XVIII. Na realidade brasileira hoje, substâncias como o álcool e a nicotina, comprovadamente danosas, são lícitas e podem ser consumidas livremente, enquanto a maconha, que possui potencial medicinal ${ }^{11}$, é rotulada como ilícita.

Não há que se perder de vista que quando se menciona em conveniência política, o sentido que está se referindo é naquilo que é agradável no momento, seja pelo pensamento dominante nos poderes (ex. conservador, liberal, progressista) corroborada pelo conservadorismo presente na sociedade em geral, endurecendo o sentido jurídico-moral que está atrelado à política de drogas, mas também a interesses econômicos camuflados na criação dessas políticas. O que se pretende demonstrar é que existe uma escolha quanto ao que é criminalizado e que essa escolha é orientada pelos valores políticos narrados acima.

A dificuldade em entender as ações das drogas, seus efeitos sociais e de como lidar com eles, potencializa problemas relacionados ao uso de psicoativos ilícitos (MACRAE, 1997). Neste sentido, Rosa del Olmo (1990) leciona que os estereótipos $^{12}$ criados em torno da discussão das drogas, além de contribuir para reforçar a confusão, servem para organizar a dar sentido às ideologias dominantes e, por este motivo, o político e o econômico estão ocultos.

No Brasil a menção sobre a regulação de drogas vem desde as Ordenações Filipinas, mas o controle sobre substâncias ainda era incipiente. Com o passar dos tempos, somando-se a pressão internacional, tendo em vista que o Brasil era - e ainda é - signatário das Nações Unidas, e as relações com os Estados Unidos, foram molas propulsoras para o enrijecimento da política de drogas no país.

A classe médica possui grande influência na consolidação da política proibicionista no Brasil, motivo justificado pelo domínio que possuíam no manejo da saúde pública. Boiteux (2006) explica que enquanto nos Estados Unidos foram os

\footnotetext{
${ }^{11}$ A política proibicionista reflete diretamente no desenvolvimento de estudos das substâncias tidas hoje como ilícitas. Apesar disso, sabe-se que a maconha tem forte potencial no uso medicinal, e é cada vez mais comum, por meio da judicialização, a liberação do uso em pessoas portadoras de enfermidades.

12 Os estereótipos que rondam a questão das drogas, advém dos mais variados fatores: o desconhecimento por parte da população quanto às drogas, a interação das pessoas com as substâncias, entre outros. Não se trata de uma apologia, mas da defesa de uma análise objetiva e contextualizada da situação (BUCHER; OLIVEIRA, 1994).
} 
ISSN no 2359-0106

Vol. 8, n. 2, 2021.

DOI 10.20873/uft.2359-0106.2021.v8n2.p526-556

juristas, políticos e religiosos que ficaram à frente da política proibicionista, no Brasil o anseio pelo controle penal das drogas foi reivindicado por médicos legistas e psiquiatras.

Após os anos 1940, o Brasil avança na esteira para o endurecimento no tratamento das drogas no país e é na década de 1960, com o advento da Convenção Única sobre Entorpecentes da ONU, que o Brasil oficialmente inicia a guerra às drogas.

O proibicionismo presente no Brasil é uma política de subserviência, pois este modelo foi importado seguindo as diretrizes estadunidenses e, além da subordinação, esse arquétipo implantado da maneira como foi impulsionou uma verdadeira política de morte. A aculturação fez com que o Brasil adotasse a ideia de que as drogas devem ser combatidas com maior rigor penal e esse fator é potencializado levando em consideração a própria base histórica brasileira, onde está presente resquícios da ditadura militar de 1964-1985. Nesta perspectiva, "Se há uma herança que o regime militar deixou à população brasileira, foi a credibilidade, forçosa ou não, que se passou atribuir ao medo como solução de questões sociais (VALOIS, 2017, p. 345).

O direito penal deixa de ser a ultima ratio para ocupar um primeiro plano, justificado pela forma como é visto o tratamento das mais diversas questões sociais e a pena passa a ser vista como vingança, e como resultado as "tentativas de dar conta desses problemas através de legislação repressiva têm criado outras ameaças às liberdades democráticas" (MACRAE, 1997, p. 109).

\subsection{GUERRA ÀS DROGAS: Breves considerações à luz da Criminologia Crítica}

Atualmente o Brasil por meio da política proibicionista está em guerra declarada: a guerra às drogas. Se desde os anos 1960 o Brasil, por meio de leis mais duras para o tratamento das drogas, declarou guerra a elas, essa luta está completando mais de sessenta anos e, apesar de serem divulgados periodicamente apreensões de quantidades expressivas das mais variadas substâncias rotuladas como ilícitas, essa guerra não surte efeitos. O motivo disso é que nesta guerra não existe lado vencedor e lado perdedor, 


\begin{abstract}
Usuários e comerciantes não são um exército contra o qual está se combatendo, por isso é impossível vencer essa guerra. Não obstante se armarem, os comerciantes, devido a circunstâncias criadas pela própria guerra, não são soldados, não estão no meio social para o combate, nem para vencer, por isso não se pode também perder a guerra (...) o termo guerra apresenta essa dificuldade, a de nossos governantes terem que assumir, perante uma sociedade atônita e apática, algo que para eles pode soar como derrota, ao reconhecerem a necessidade do fim da guerra às drogas (VALOIS, 2017, pp. 525-6)
\end{abstract}

Nesta guerra um verdadeiro estado de exceção é minado, decorrente da violência envolvida. Enquanto a ilegalidade faz com que grupos, advindo principalmente de facções, entrem em campo a fim de monopolizar o comércio de drogas no país, disputando as melhores rotas do tráfico, pensando em uma questão de logística, a segurança pública entra em ação para impedir esses grupos. Deste campo de disputa por espaço (traficantes pelo monopólio do comércio e segurança pública no combate aos primeiros), um rastro de destruição vai ficando pelo caminho ${ }^{13}$.

No relatório divulgado pelo Conselho Nacional de Justiça $(\mathrm{CNJ})$, o tráfico de drogas é o segundo tipo penal mais recorrente imputado às pessoas privadas de liberdade no país (BRASIL, 2018), em 2019 eram 200.583 pessoas presas com incurso na lei de drogas (BRASIL, 2019).

Mas qual o papel da criminologia ${ }^{14}$, em especial da criminologia crítica, na compreensão da guerra às drogas? Neste ponto, primeiro deve-se ser entendido o motivo pelo qual a criminologia crítica é importante. Baratta (2002) aduz que pelo fato da oposição ao enfoque biopsicológico, a criminologia crítica "ilumina a relação funcional ou disfuncional com as estruturas sociais, com o desenvolvimento das relações de produção e de distribuição" (p. 160), esse giro epistemológico aprofundou a importância da criminologia na compreensão do fenômeno crime. As drogas e todo o seu processo de criminalização, motivadas pelas questões discutidas nos tópicos anteriores, demonstra que as sociedades capitalistas utilizam

${ }^{13}$ Agatha Felix de oito anos de idade foi morta com um tiro nas costas no Rio de Janeiro em 2019 numa operação da Polícia Militar para combater o tráfico de drogas, ela representa uma das tantas vítimas deste estado de exceção (FARIAS, 2019).

14 Importante ressaltar que não é possível dizer em criminologia, no singular, justamente por não existir e não comportar toda a diversidade que o campo criminológico abrange (ANDRADE, 2013). 
os mecanismos de controle social, o direito penal neste caso, para a manutenção do status quo, ou seja, da sociedade de classes.

Além disso, "a criminologia enquanto práxis constitui o mais efetivo instrumento de crítica ao mito da neutralidade ideológica do Direito Penal bem como autoriza a deslegitimação da pena de prisão como instrumento principal de controle social das sociedades periféricas" (SHECAIRA, 2014, p. 9). A teoria crítica desnuda todas as mazelas que estão camufladas na guerra às drogas, expondo a face mais perversa da humanidade nas sociedades capitalistas.

Pensar a questão criminal e tudo que o tema envolve é um ato complexo, consequentemente o que se pensará para administrar também será por vias complexas, por este motivo as soluções superficiais, além de não resolverem, agravam problemas do contexto social,

\begin{abstract}
na perspectiva da criminologia crítica a criminalidade não é mais uma qualidade ontológica de determinados comportamentos e de determinados indivíduos, mas se revela, principalmente, como um status atribuído a determinados indivíduos, mediante uma dupla seleção: em primeiro lugar, a seleção dos bens protegidos penalmente, e dos comportamentos ofensivos destes bens, descritos nos tipos penais; em segundo lugar, a seleção dos indivíduos estigmatizados entre todos os indivíduos que realizam infrações a normas penalmente sancionadas (BARATTA, 2002, p. 161)
\end{abstract}

A figura do traficante não é odiada por levar a substância vinda do inferno, mas a sua morte é desejada por lucrar com a empreitada. Como não existe possibilidade de se ganhar a guerra, a morte do outro é vista como uma vitória (VALOIS, 2017).

A guerra às drogas também deve ser vista a partir do recorte de raça. Diversos fatores, do ponto de vista crítico, colocam em evidência a manutenção de um poder colonial, Borges (2018) frisa que a guerra às drogas funciona como uma reconfiguração do sistema colonial, perpetuando discriminações e exclusões:

Se este sistema [justiça criminal] já operou explicitamente pela lógica da escravidão, passando pela vigilância e controle da população negra após a proclamação da República, pela criminalização da cultura e apagamento memória afrodescendente, percorrendo a aculturação e assimilação pela mestiçagem e apropriação, negação do acesso à educação, saneamento, saúde - questões que permanecem, inclusive - hoje não temos um cenário de fim dessa engrenagem, mas de seu remodelamento (BORGES, 2018, p. 18) 
Trocando em miúdos, a criminologia crítica representa a lente pela qual devese olhar a guerra às drogas - e o sistema de justiça criminal - para compreender as condições de criminalização.

A despeito de ser uma questão de importância extrema, não será o enfoque do presente estudo. Todavia, será lançado luz na discussão pela abordagem da variável raça dentro dos procedimentos policiais analisados, por entender que a teoria crítica quando coloca em julgamento o sistema de justiça criminal abrangendo questões relativas à classe, também deve ser vista com o enfoque no racismo. Neste ponto o racismo é considerado não só um fator de divisão entre classes, mas também no interior das classes (ALMEIDA, 2019). E assim, frisam Borges (2018), Almeida (2019), Flauzina (2006).

\section{LEI DE DROGAS: Caminhos para identificar usuários e traficantes em Pontes e Lacerda/MT}

\subsection{A LEI 11.343/2006: Construindo o desenho metodológico}

A Lei de Drogas é decorrente do proibicionismo vigente. A partir disso, proibidas determinadas substâncias, o sistema de justiça criminal entra em ação para cumprir aquilo positivado. Neste sentido, é possível dizer que o principal objeto de estudo desta pesquisa é a Lei 11.343/2006.

Além da análise documental e bibliográfica, a pesquisa possui caráter quantitativa, e foi dividida em dois momentos: i) a coleta de dados a campo, onde foi tabulada as informações consideradas relevantes para o escopo da pesquisa; ii) num segundo momento, reunidas as informações, foi realizada uma exposição analítica sobre os achados da pesquisa, realizando correlações com paradigmas da criminologia crítica.

O pesquisador Alex Penazzo Tavares, por exercer estágio ${ }^{15}$ supervisionado na Delegacia Regional de Pontes e Lacerda ${ }^{16}$ e estar em contato com a atuação

\footnotetext{
15 Estágio realizado no período de 20/05/2019 a 12/03/2021.

16 Dentro da estrutura organizacional da Polícia Judiciária Civil de Mato Grosso, a Delegacia Regional é responsável administrativamente pelas unidades circunscritas. No caso da Regional de Pontes e Lacerda, fazem parte da circunscrição as delegacias dos municípios de Campos de Júlio, Comodoro, Jauru, Pontes e Lacerda, Rondolândia e Vila Bela da Santíssima Trindade.
} 
ISSN n 2359-0106

Vol. 8, n. 2, 2021.

DOI 10.20873/uft.2359-0106.2021.v8n2.p526-556

policial na localidade, não enfrentou dificuldades quanto o acesso ao material de pesquisa. A partir de autorização da Delegada Titular da Delegacia municipal de Pontes e Lacerda, em dias e horários previamente ajustados com a Autoridade Policial e com a chefe do cartório central da Unidade Policial, compareceu à Delegacia para realizar a busca dos dados.

Cabe ressaltar que o estudo é guiado analisando a aplicação da Lei de Drogas em âmbito municipal no mês de maio de 2019. O mês de maio foi escolhido por ser o mês com maior número de apreensões no ano de 2019, essa informação foi obtida junto ao sistema Gview, módulo que faz parte do conjunto de sistemas da PJC/MT. Com esses procedimentos listados, foi realizada uma nova busca com auxílio da Escrivã chefe do cartório central da delegacia de polícia, refinando a lista e separando somente dos Inquéritos Policiais e Termos Circunstanciados de Ocorrência que tratassem de tráfico de drogas e porte de drogas.

Foi montado uma planilha no software Excel, a fim de estabelecer quais informações seriam coletadas e depois expostas no presente artigo. Após a busca no arquivo da Delegacia, em espaço cedido pelos servidores, foi realizada uma leitura minuciosa dos autos e catalogadas as variáveis desejadas na planilha mencionada.

Os procedimentos policiais de uma delegacia são fontes inesgotáveis de informações para se construir pesquisas que auxiliam na compreensão de uma gama de fatores que estão presentes no seio social. É por meio destes documentos que o Estado pode exercer o controle de corpos (FERREIRA; NADAI, 2015).

Numa pesquisa que mobilize documentos é exigido do pesquisador uma posição diferente daquela adotada na confecção de uma peça processual, por exemplo. Na pesquisa documental o pesquisador é guiado por objetivos definidos (cientificamente e teoricamente), pois a qualidade da evidência irá influenciar na validade e confiabilidade da pesquisa (REGINATO, 2017). Nesta perspectiva, buscando realizar um estudo dentro dos parâmetros de validade científica, consubstanciando a concretude daquilo posto de frente ao pesquisador, o corpus da pesquisa detalha a experiência dentro da unidade policial com a documentação explorada. 
Apesar de alguns documentos dos procedimentos analisados estarem no sistema institucional ${ }^{17}$ da Polícia Judiciária Civil de Mato Grosso, portanto online, optou-se por analisar os documentos físicos originais disponíveis no arquivo da delegacia, justamente por este sistema ainda não estarem todos os documentos produzidos nas investigações criminais objetos de estudo.

Entretanto, enfrentou-se dificuldades em analisar todos os procedimentos que estavam previstos quando da elaboração do projeto da pesquisa. Pois, após realizada as formalidades da prisão ou autuação, os autos são encaminhados ao Poder Judiciário ${ }^{18}$, e a delegacia de polícia mantém em arquivo uma cópia.

Como visto no tópico anterior, desde a segunda metade do século $\mathrm{XX}$ o governo brasileiro conduz a guerra às drogas no território nacional. Atualmente, é a lei 11.343/2006, conhecida como lei de drogas, que realiza a gerência do proibicionismo. Esta lei instituiu o Sistema Nacional de Políticas Públicas sobre Drogas (SISNAD), prescreve medidas para prevenção do uso indevido, atenção e reinserção social de usuários e dependentes de drogas, além de prever formas de repressão ao tráfico, assim como faz a definição de crimes (BRASIL, 2006).

Enfrenta-se um primeiro impasse com a legislação de drogas brasileira: a dificuldade em conceituar o que é droga. O parágrafo único, do artigo primeiro da Lei 11.343/2006 estabelece que "consideram-se como drogas as substâncias ou os produtos capazes de causar dependência, assim especificados em lei ou relacionados em listas atualizadas periodicamente pelo Poder Executivo da União" (BRASIL, 2006), ou seja, não é a lei de drogas que especifica quais drogas são consideradas ilícitas, mas sim outra norma infraconstitucional ${ }^{19}$, MaCrae (1997, p. 113) leciona que:

quem realiza a listagem de entorpecentes é uma outra instância, burocrática e não representativa, deixando-se de apresentar até uma definição mais exata das características farmacológicas que tornariam determinadas substâncias passíveis de proibição

17 Referência ao sistema Geia

18 Recentemente, com o desenvolvimento do sistema institucional, esses procedimentos são protocolados via Processo Judicial Eletrônico (PJE) e assim seguem o trâmite processual de forma virtual.

19 Trata-se de uma norma penal em branco, pois, para sua aplicação, é imprescindível a discriminação das drogas ilícitas na Portaria SVS/MS no 344/1998. Isto é, para aplicação da lei de drogas é necessário o_complemento de uma outra norma. 
DOI 10.20873/uft.2359-0106.2021.v8n2.p526-556

Essa instituição a que se refere o autor é a Agência Nacional de Vigilância Sanitária (ANVISA), agência reguladora vinculada ao Ministério da Saúde brasileiro. É por meio da Portaria SVS/MS no $344 / 1998$ que é feito o regulamento técnico sobre substâncias e medicamentos sujeitos a controle especial no país. Nesta portaria estão descritas todas as substâncias consideradas ilícitas no país, sendo atualizada frequentemente pela autarquia ${ }^{20}$, subsidiando, assim, a aplicação da lei de drogas no país.

O conceito genérico sobre o que será considerado droga causa confusões, pois "substâncias ou os produtos capazes de causar dependência" abrange uma grande variedade de substâncias consumidas livremente no seio social, MacRae (1997, p. 110), sublinha que:

é uma definição demasiadamente ampla para o cientista social ou o legislador, já que a rigor incluiria desde a heroína injetável ou o crack, como utilizados entre os setores sociais mais marginalizados, passando pelo álcool e tabaco, altamente promovidos como símbolos de prestígio e chegando a incluir o próprio vinho utilizado na comunhão cristã, um dos momentos privilegiados de confirmação e propagação dos valores emblemáticos da sociedade ocidental.

Noutro ponto, o artigo primeiro da Portaria SVS/MS nํ344/1998 define droga e entorpecente como:

Droga - Substância ou matéria-prima que tenha finalidade medicamentosa ou sanitária.

Entorpecente - Substância que pode determinar dependência física ou psíquica relacionada, como tal, nas listas aprovadas pela Convenção Única sobre Entorpecentes, reproduzidas nos anexos deste Regulamento Técnico (BRASIL, 1998).

20 O processo de inclusão de Novas Substâncias Psicotrópicas (NSP) no anexo I da Portaria no 344/1998, envolve algumas discussões ainda pouco claras. A pesquisa de Soares e Zackseski (2016) demonstra que as novas substâncias que foram listadas careciam de informações técnicas sobre as substâncias quanto aos seus efeitos adversos à saúde, toxicidade e dependência, para as pesquisadoras restou claro que ainda que envolvesse dúvida no processo de inclusão da nova substância na lista, o proibicionismo possui uma presunção que pesa a seu favor, e, portanto, foram incluídas na portaria. 
DOI 10.20873/uft.2359-0106.2021.v8n2.p526-556

Mas a Lei de Drogas, em que pese ser posterior a Portaria SVS/MS no 344/1998, preferiu generalizar com o termo drogas, conforme previsão do artigo $66^{21}$.

Além do mais, a Lei 11.343/2006 é ambígua em prever as condutas criminosas, especificamente quanto à conduta de traficância e de uso de drogas. $O$ artigo 28 da Lei 11.343/2006, dispõe que

Art. 28. Quem adquirir, guardar, tiver em depósito, transportar ou trouxer consigo, para consumo pessoal, drogas sem autorização ou em desacordo com determinação legal ou regulamentar será submetido às seguintes penas: I - advertência sobre os efeitos das drogas; II - prestação de serviços à comunidade; III - medida educativa de comparecimento a programa ou curso educativo.

$\S 1^{\circ}$ Às mesmas medidas submete-se quem, para seu consumo pessoal, semeia, cultiva ou colhe plantas destinadas à preparação de pequena quantidade de substância ou produto capaz de causar dependência física ou psíquica.

$\S 2^{\circ}$ Para determinar se a droga destinava-se a consumo pessoal, o juiz atenderá à natureza e à quantidade da substância apreendida, ao local e às condições em que se desenvolveu a ação, às circunstâncias sociais e pessoais, bem como à conduta e aos antecedentes do agente.

Para tanto, aqueles que incorrerem nos termos do artigo 28 , serão enquadrados como usuários de drogas e poderão ser penalizados ${ }^{22}$ de acordo com os incisos do artigo. Além da tipificação não ser objetiva, soma-se o fato do parágrafo segundo representar a apreciação mais subjetiva possível do julgador.

Tramita no Supremo Tribunal Federal (STF) o Recurso Extraordinário (RE) no 635659/SP, com reconhecimento de repercussão geral, interposto pela Defensoria Pública de São Paulo, tratando sobre a tipicidade do porte de droga para consumo pessoal. O ministro Gilmar Mendes votou pela inconstitucionalidade do artigo 28 da Lei 11.343/2006 e defendeu o deslocamento do tratamento da esfera penal para o âmbito cível (BRASIL, 2015).

21 "Art. 66. Para fins do disposto no parágrafo único do art. 1ํ desta Lei, até que seja atualizada a terminologia da lista mencionada no preceito, denominam-se drogas substâncias entorpecentes, psicotrópicas, precursoras e outras sob controle especial, da Portaria SVS/MS no 344, de 12 de maio de 1998" (BRASIL, 2006).

${ }^{22}$ A pena prevista no artigo 28 da Lei de drogas, caracteriza, para Boiteux (2006), o proibicionismo moderado, pelo fato do porte de droga ser praticamente despenalizado. 
DOI 10.20873/uft.2359-0106.2021.v8n2.p526-556

Por outro lado, o artigo $33^{23}$ da Lei 11.343/2006, com penalização mais severa, prevê a conduta de tráfico de drogas,

\begin{abstract}
Art. 33. Importar, exportar, remeter, preparar, produzir, fabricar, adquirir, vender, expor à venda, oferecer, ter em depósito, transportar, trazer consigo, guardar, prescrever, ministrar, entregar a consumo ou fornecer drogas, ainda que gratuitamente, sem autorização ou em desacordo com determinação legal ou regulamentar: Pena - reclusão de 5 (cinco) a 15 (quinze) anos e pagamento de 500 (quinhentos) a 1.500 (mil e quinhentos) dias-multa.
\end{abstract}

Os dois artigos ${ }^{24}$, apesar de preverem condutas distintas, não as tratam com a devida distinção, uma verdadeira zona cinzenta está presente nas tipificações penais, abrindo margem para a subjetividade quanto ao tratamento de usuários e traficantes de drogas, e assim punindo em sua maioria nas penas do tráfico.

Em decorrência desta não delimitação, a aplicação da lei de drogas fica em um estado de indecisão. Por este motivo, pesquisadores do tema apontam para uma seletividade no sistema penal e a política de drogas funcionando "como legitimadora do tradicional modelo criminalizador da pobreza no Brasil" (BOITEUX, 2009, p. 23).

$\mathrm{Na}$ realidade, o fato da norma não delimitar as duas situações (tráfico e uso), acaba por inverter o ônus da prova ${ }^{25}$ cabendo a pessoa indiciada provar que o fato é de porte de droga e não de tráfico. Caracteriza-se, assim, violação ao princípio da presunção de inocência previsto na Constituição Federal de 1988, pois quando uma pessoa é flagrada com drogas, presumidamente, será considerada traficante.

A pesquisa de Boiteux (2009) realizada analisando as sentenças da capital do país, Brasília, e da cidade do Rio de Janeiro, demonstrou que mais de metade $(68,7 \%)$ das pessoas condenadas como traficantes em Brasília possuíam menos de 100 gramas de maconha (cannabis), revelando assim que pequenas quantidades de drogas são consideradas como tráfico.

Situação semelhante é observada por Cardoso e Ramos (2020) em Belém/PA: condenações por tráfico de pequenas quantidades de drogas.

${ }^{23} \mathrm{O}$ tráfico de drogas é um crime de perigo abstrato, ou seja, existe a probabilidade de dano ao bem jurídico tutelado (saúde pública) independente da prova do dano (dano presumido) ( $\mathrm{NUCCl}, 2020)$.

${ }^{24} \mathrm{Em}$ ambos os casos o bem jurídico protegido é a saúde pública (NUCCl, 2020).

${ }^{25} \mathrm{O}$ ônus da prova, ou seja, provar que determinada pessoa praticou um ato ilícito, antijurídico e culpávelé do titula da ação penal, no caso_é_o Ministério Público. 
ISSN no 2359-0106

Vol. 8, n. 2, 2021.

DOI 10.20873/uft.2359-0106.2021.v8n2.p526-556

Diante disso, tomando como base os apontamentos da seletividade criminal, o presente estudo se propõe em analisar se estes fatores estão presentes no oeste mato-grossense, especificamente na cidade de Pontes e Lacerda. Entretanto, nesta pesquisa será analisada uma ponta do sistema de justiça criminal, qual seja, a delegacia de polícia.

É a partir da atuação policial que poderá haver o início de um processo criminal, portanto são as instituições policiais que realizam o primeiro contato com um possível autor e com indícios de violação da lei por este autor. Por esse motivo, a análise da pesquisa é restrita aos procedimentos investigatórios que têm início com uma portaria da Autoridade Policial ou por meio de Auto de Prisão em Flagrante (APF) e o término com o relatório confeccionado também pela Autoridade Policial, conforme previsão do Código de Processo Penal.

\subsection{O USUÁRIO E O TRAFICANTE DE DROGAS EM PONTES E LACERDA/MT}

O estado de Mato Grosso possui uma longa faixa fronteiriça com a Bolívia, somando 983 quilômetros de fronteira seca e alagada (MATO GROSSO, 2018). A cidade de Pontes e Lacerda, fazendo parte dos municípios do estado que estão nesta linha fronteiriça, é estratégica para a comunicação e transporte com o país vizinho, sendo utilizada, também, como rota do tráfico de drogas.

Por ser um município que as drogas ilícitas estão fortemente presentes, os dados desta pesquisa lançam luz sobre dinâmicas presentes na atuação policial no enfrentamento às drogas na localidade, identificando os atores que estão envolvidos nesta atividade.

$\mathrm{Na}$ tabela 1 foi sistematizada os procedimentos policiais analisados, a espécie e quantidade de droga apreendida e se a pessoa foi atuada como traficante ou usuário.

Tabela 1 - Detalhamento dos procedimentos do mês de maio de 2019 analisados com quantidade de droga.

\begin{tabular}{|c|c|c|c|}
\hline Procedimento & Espécie & Quantidade & Tráfico ou uso? \\
\hline
\end{tabular}


ISSN n' 2359-0106

Vol. 8, n. 2, 2021.

DOI 10.20873/uft.2359-0106.2021.v8n2.p526-556

\begin{tabular}{|c|c|c|c|}
\hline BOC 114.6.2019.888 & Maconha & $\begin{array}{l}3.278,67 \mathrm{Kg} \text { (três mil } \\
\text { duzentos e setenta e } \\
\text { oito gramas e sessenta } \\
\text { e sete centigramas) }\end{array}$ & Tráfico \\
\hline IP 114.4.2019.16755 & Cocaína & $\begin{array}{l}56,394 \mathrm{Kg} \text { (cinquenta e } \\
\text { seis quilogramas e } \\
\text { trezentos e noventa e } \\
\text { quatro centigramas) }\end{array}$ & Tráfico \\
\hline IP 114.4.2019.18800 & Cocaína & $\begin{array}{l}24,67 \text { g (vinte quatro } \\
\text { gramas e sessenta e } \\
\text { sete centigramas) }\end{array}$ & Tráfico \\
\hline IP 114.4.2019.19393 & $\begin{array}{l}\text { Cocaína e } \\
\text { maconha }\end{array}$ & $\begin{array}{l}\text { 13,12 g (treze gramas e } \\
\text { doze centigramas de } \\
\text { cocaína) e } 0,45 \mathrm{cg} \\
\text { (quarenta e centigramas } \\
\text { de maconha) }\end{array}$ & Tráfico \\
\hline IP 114.4.2019.19373 & Cocaína & $\begin{array}{l}5,41 \text { g (cinco } \\
\text { quaramas e } \\
\text { centigramas) }\end{array}$ & Tráfico \\
\hline IP 114.4.2019.19455 & Cocaína & $\begin{array}{l}4847,11 \mathrm{Kg} \text { (quatro mil } \\
\text { oitocentos e quarenta e } \\
\text { sete gramas e onze } \\
\text { centigramas }\end{array}$ & Tráfico \\
\hline IP 114.4.2019.19537 & Cocaína & $\begin{array}{lcr}257 \quad \text { g } & \text { (duzentos } & \text { e } \\
\text { cinquenta } & \text { e } & \text { sete } \\
\text { gramas) } & & \end{array}$ & Tráfico \\
\hline IP 114.4.2019.20702 & Maconha $^{26}$ & Informação inexistente & Tráfico \\
\hline IP 114.4.2019.18715 & Maconha & $\begin{array}{l}0,26 \mathrm{cg} \text { (vinte e seis } \\
\text { centigramas) }\end{array}$ & Uso \\
\hline IP 114.4.2019.18832 & Maconha & $\begin{array}{l}41,68 \mathrm{~g} \text { (quarenta e } \\
\text { uma gramas e sessenta } \\
\text { e oito centigramas) }\end{array}$ & Tráfico \\
\hline IP 114.4.2019.19538 & Cocaína & $\begin{array}{l}977,4 \mathrm{~g} \text { (novecentos e } \\
\text { setenta e sete gramas e } \\
\text { quarenta centigramas) }\end{array}$ & Tráfico \\
\hline IP 114.4.2019.16741 & Cocaína & 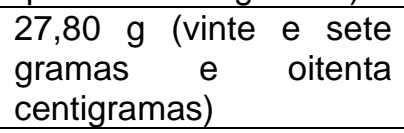 & Tráfico \\
\hline IP 114.4.2019.18436 & Cocaína & $\begin{array}{l}17,51 \text { g (dezessete } \\
\text { gramas e cinquenta e } \\
\text { um centigramas) }\end{array}$ & Tráfico \\
\hline TCO 114.5.2019.9236 & Maconha & $\begin{array}{l}1,52 \text { g (um grama e } \\
\text { cinquenta e dois } \\
\text { centigramas) }\end{array}$ & Uso \\
\hline
\end{tabular}

Fonte: Elaboração própria.

Percebe-se que a maioria das apreensões são de pequenas quantidades de drogas (abaixo de 100 gramas $^{27}$ ) e cerca de $85 \%$ (oitenta e cinco por cento) das

26 No IP não estava juntando o laudo pericial, responsável pelo atesto de que a substância apreendida é realmente_uma substância ilícita, bem como a quantidade. 
pessoas autuadas no mês de Maio de 2019 foram enquadradas no artigo 33 da Lei de Drogas (tráfico). Além disso, todas foram autuadas em flagrante ${ }^{28}$, sendo três resultantes de cumprimento de mandado de busca e apreensão.

A delegada de polícia é a primeira autoridade do sistema de justiça criminal responsável pelo enquadramento legal da pessoa presa em flagrante. Desta forma, considerando os elementos que the são trazidos pelos policiais que efetuaram a abordagem, é a Autoridade Policial que irá determinar a capitulação do crime. Por não ter parâmetros objetivos, um poder de discricionariedade é dado à polícia ${ }^{29}$.

Obtendo os dados dos procedimentos acima mencionados, tem-se que a maioria das pessoas que estavam envolvidas eram homens, conforme consta no gráfico 1.

Gráfico 1 - Distribuição de pessoas autuadas por gênero.

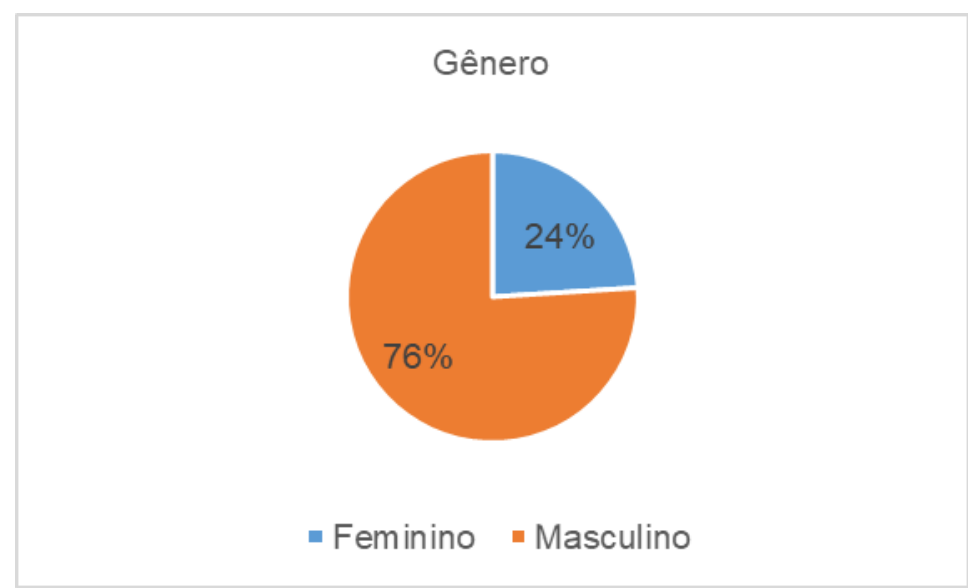

Fonte: elaboração própria (valores arredondados).

Quanto a raça, constatou-se que a maioria das pessoas são pardas, como apresentado no gráfico 2.

${ }_{27}$ Conforme mencionado trecho acima, a pesquisa de Boiteux (2009) demonstrou que em Brasília e no Rio de Janeiro pessoas condenadas como como traficantes, possuíam menos de 100 gramas de drogas.

28 É considerado flagrante de delito, de acordo com o artigo 302 do Código de Processo Penal (CPP), "I-quem está cometendo a infração penal; II - acaba de cometê-la; III) é perseguido, logo após, pela autoridade, pelo ofendido ou por qualquer pessoa, em situação que faça presumir ser autor da infração; IV - é encontrado, logo depois, com instrumentos, armas, objetos ou papéis que façam presumir ser ele autor da infração" (BRASIL, 1941).

${ }^{29}$ Apesar de haver possibilidade de denúncia no futuro por parte do Ministério Público, o órgão ministerial não está vinculado a capitulação legal dada em sede policial, podendo ter entendimento diverso. 
ISSN n' 2359-0106

Vol. 8, n. 2, 2021.

DOI 10.20873/uft.2359-0106.2021.v8n2.p526-556

Gráfico 2 - Distribuição das pessoas autuadas por raça.

Raça

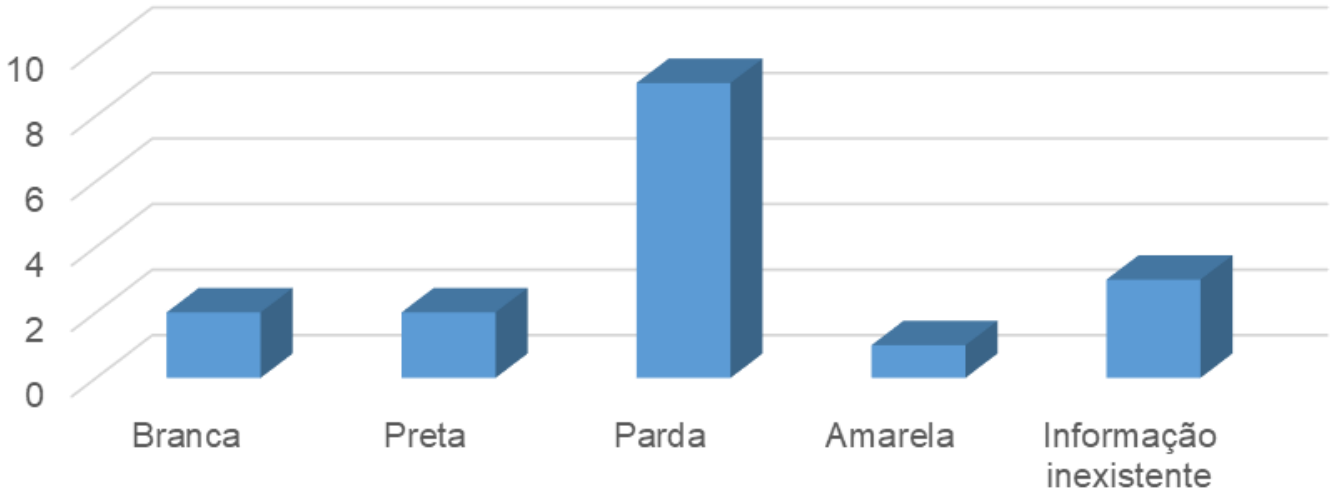

Fonte: elaboração própria.

A informação quanto a raça foi retirada dos próprios autos, não sendo possível afirmar que se trata de autodeclaração do indivíduo. Por não ser a abrangência do presente artigo, a constatação fica restrita aos elementos informativos descritos.

Ainda na variável social, tem-se a constatação de que as pessoas envolvidas são, em sua maioria, jovens de 18 a 29 anos, conforme sistematizado no gráfico 3 .

Gráfico 3 - faixa etária das pessoas autuadas

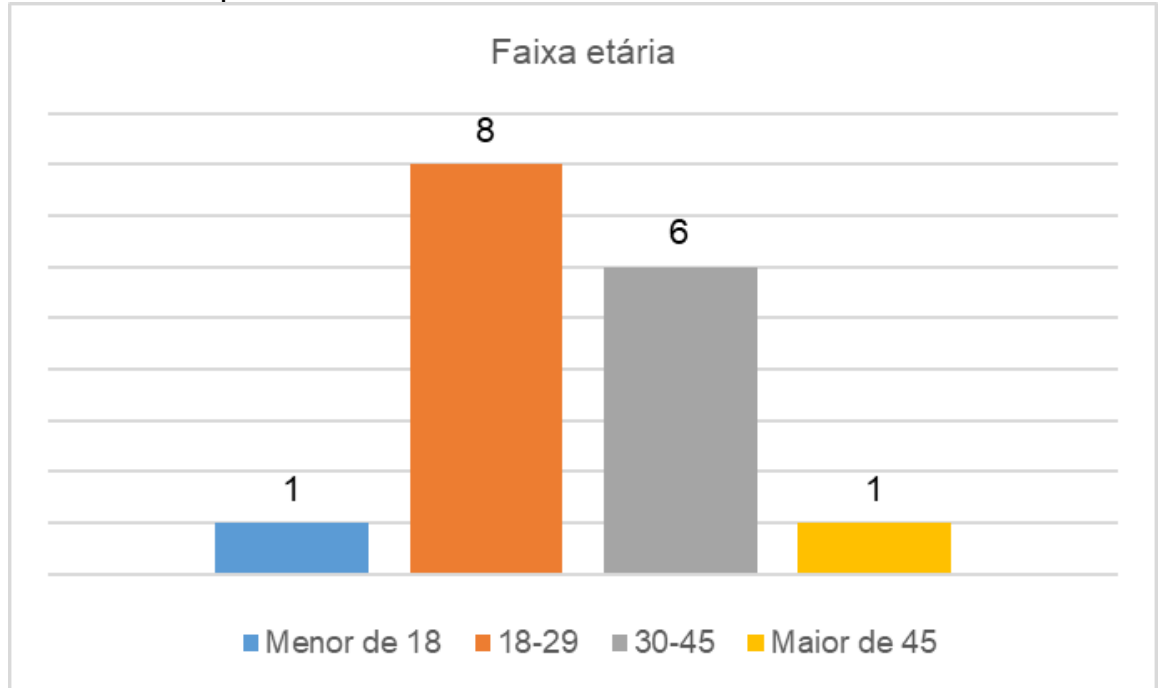

Fonte: elaboração própria.

No interrogatório realizado na delegacia, primeiro momento em que a pessoa autuada poderá falar acerca dos fatos, é realizado questionamentos quanto a 
ISSN no 2359-0106

Vol. 8, n. 2, 2021.

DOI 10.20873/uft.2359-0106.2021.v8n2.p526-556

qualificação e vida pregressa. Diante disso, analisando estes interrogatórios, extraiuse informações de cunho econômico das pessoas, conforme o gráfico 4 a seguir.

Gráfico 4 - Informação econômica levando em consideração o salário mínimo vigente no ano de 2019 $(\mathrm{R} \$ 998,00)$.
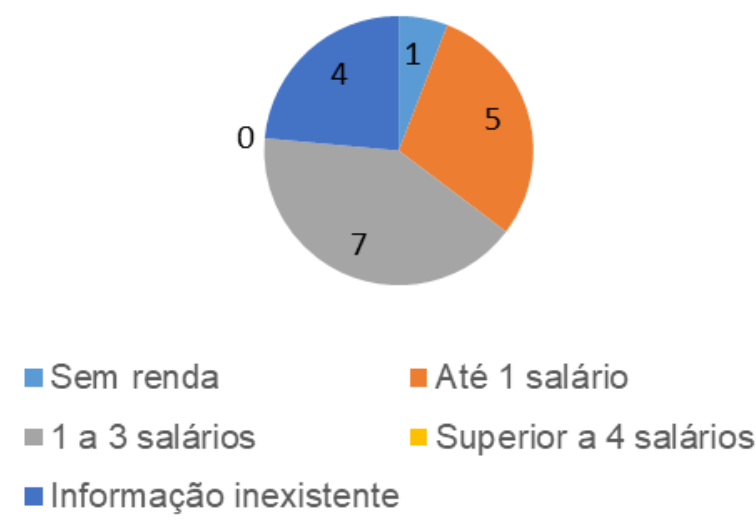

Fonte: elaboração própria.

A maioria das pessoas possuíam renda, aproximadamente, de 1 (um) até 3 (três) salários mínimos. Ressalta-se que, dos casos objetos de análise, nenhuma das pessoas possuía renda acima de 4 (quatro) salários, demonstrando que majoritariamente são pessoas com baixo poder aquisitivo.

Correlacionando com a criminologia crítica, é possível dizer, com os dados acima apresentados, que a maior incidência do envolvimento de pessoas pobres no tráfico e a cifra oculta do consumo de droga entre pessoas não pobres, demonstra que o controle penal não é reativo à transgressão e coloca em dúvida a atuação em defesa da saúde pública. Isto é, coloca em evidência que a guerra às drogas é uma guerra contra a classe pobre (REZENDE, 2011).

O tráfico de drogas, na perspectiva da classe social pobre, é visto como uma forma possível de ascendência dentro da sociedade capitalista. As vultuosas quantias resultantes do tráfico de drogas trazem aos envolvidos reconhecimentos dentro de sua comunidade, por este motivo o tráfico de drogas está intrinsecamente ligado também a economia capitalista (FARIA; BARROS, 2011).

Outra variável analisada refere-se à polícia que realizou a apreensão, conforme consta no gráfico abaixo: 
ISSN no 2359-0106

Vol. 8, n. 2, 2021.

DOI 10.20873/uft.2359-0106.2021.v8n2.p526-556

Gráfico 5 - apreensões totais realizadas por polícia.

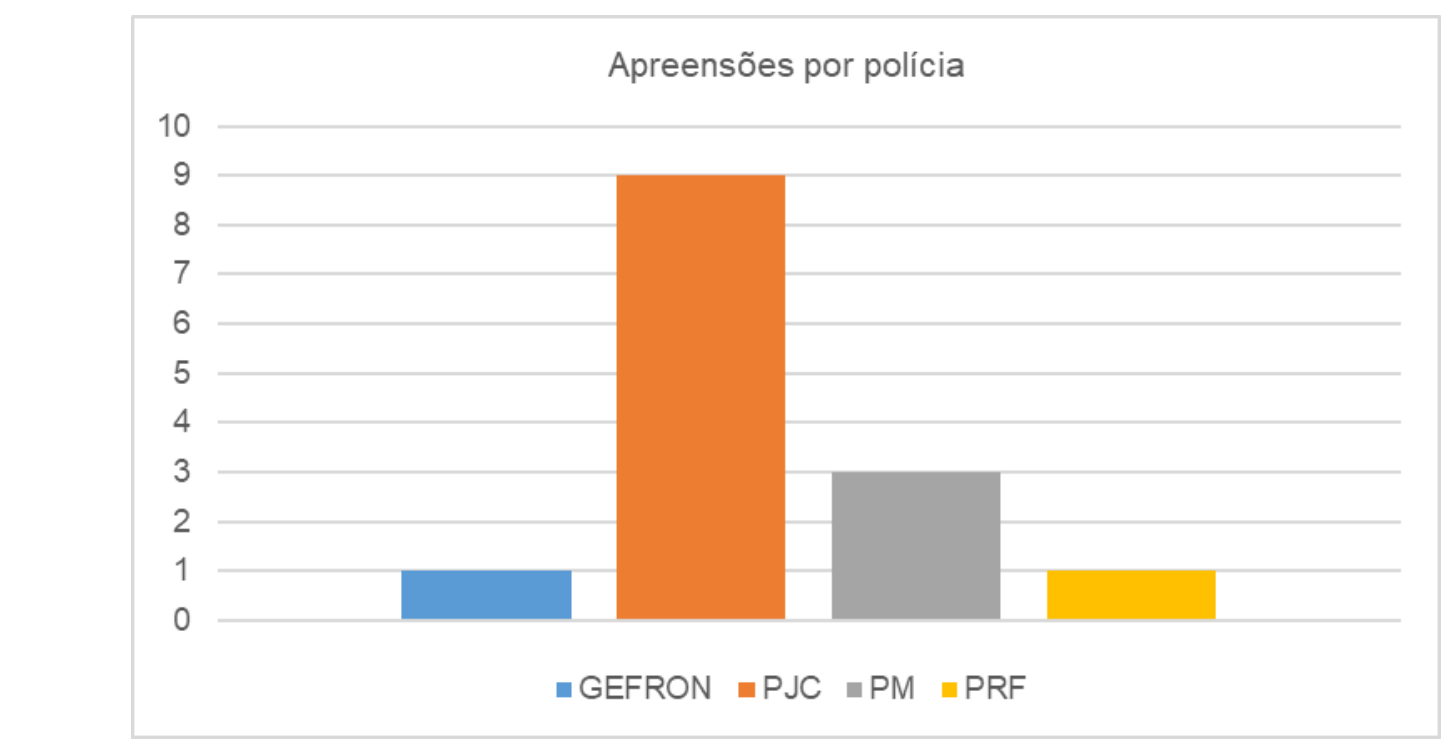

Fonte: elaboração própria.

A atuação do Grupo Especial de Fronteira (GEFRON) ${ }^{30}$ é estrategicamente direcionada à fronteira com a Bolívia, isso pode explicar as vultosas quantidades de drogas apreendidas (tráfico internacional). Especificamente a apreensão que originou O IP $\mathrm{n}^{\circ}$ 114.4.2019.16755, dois homens foram presos em flagrante por estarem realizando o transporte de mais de 56 (cinquenta e seis) quilos de cocaína.

A Polícia Rodoviária Federal (PRF), como se sabe, atua nas rodovias federais brasileiras e nas áreas de interesse da União. Na apreensão realizada no Boletim de Ocorrência Circunstanciado (BOC) 114.6.2019.888, a droga era transportada por uma adolescente que realizava o transporte da substância de Manaus/AM para Cuiabá/MT.

Os dois casos acima caracterizam as pessoas conhecidas como "mulas", responsáveis pelo transporte de drogas.

Notou-se semelhança entre os inquéritos 114.4.2019.19393 e 114.4.2019.19373. Nos dois casos, os policiais civis possuíam a informação de que nas residências haveria arma de fogo, situação confirmada nas duas situações. No Inquérito Policial (IP) 114.4.2019.19373 duas testemunhas prestaram declarações e informaram que iam a casa para adquirir drogas, o autuado disse que os policiais o

30 O Grupo Especial de Fronteira (GEFRON), criado pelo decreto estadual 3.994 de 13 de março de 2002, é uma das principais ações do estado direcionada à segurança da fronteira Brasil-Bolívia. 
agrediram, sendo constatado no exame de corpo de delito lesões, e que a droga tinha sido implantada por um dos policiais. As mesmas circunstâncias estão presentes no IP 114.4.2019.19393, e foi observada a informação, juntada nos autos, que o autuado era faccionado ao Primeiro Comando da Capital (PCC) ${ }^{31}$. Na decisão que homologou o Auto de Prisão em Flagrante (APF), o magistrado concedeu liberdade provisória impondo medidas cautelares em ambos os casos.

A subjetividade presente na Lei de Drogas quanto a observância das circunstâncias por parte da autoridade, possibilita a autuação de uma pessoa como traficante mesmo com quantidade ínfima de drogas, como é o caso dos inquéritos 114.4.2019.18800, 114.4.2019.19393, 114.4.2019.19373, 114.4.2019.18832, 114.4.2019.16741 e 114.4.2019.18436 em que todos possuíam menos de cinquenta gramas de substâncias ilícitas. Observou-se nestes autos que a culminação no enquadramento como tráfico, advém de fatores como porte de arma de fogo e cédulas de dinheiro e, em alguns casos, em testemunhas.

\section{CONSIDERAÇÕES FINAIS}

O estudo mostra como o proibicionismo opera enquanto política criminal e, por conseguinte, a eclosão da guerra às drogas na atualidade. Este processo de demonização das drogas, construído desde os Estados Unidos, espalhou-se para o globo terrestre, escamoteando culturas e colocando a questão a ser tratada a partir da segurança pública.

No Brasil, a Lei 11.343/2006 exercendo o controle de substâncias ilícitas, que são especificadas em outra norma infraconstitucional, a Portaria SVS/MS no 344/1998, evidencia como o tratamento das drogas é confuso. De um lado, a abrangência do conceito de drogas e, de outro, a obscura escolha de determinadas substâncias como ilícitas.

A hipótese do estudo, no tocante a quantidade de drogas em que as pessoas são autuadas como traficantes, é confirmada na realidade da cidade de Pontes e

\footnotetext{
31 Não existem elementos que comprovem ou mesmo declaração da pessoa autuada sobre a facção. A folha juntada, retirada de um dos sistemas institucionais da PJC/MT, é preenchida pelos próprios policiais. Assim, pode-se dizer que a conclusão se trata de informações trocadas entre os policiais ou mesmo de investigações anteriores.
} 
Lacerda, no período analisado, diante da maioria dos casos tratarem de uma quantidade pequena de drogas. A subjetividade trazida pela lei, quanto à observância das circunstâncias de cada caso, deixa claro como as autoridades encontram espaço para atuar com discricionariedade.

A constatação de um perfil de pessoas demonstra que os reflexos da atual política de drogas são respingados diretamente em pessoas que estão na classe marginalizada da estrutura social. Deste fato, é possível dizer que a política de drogas brasileira funciona a todo vapor para criminalizar e massacrar a pobreza, pois os fatos isolados constatados pouco interferem na real estrutura do tráfico de drogas, tratando-se de papéis descartáveis e de fácil substituição. Dos procedimentos analisados, é possível dizer que pouco impactam no comércio de drogas na região, justamente porque o tráfico de drogas possui uma organização multifacetada e quem comanda o tráfico não é identificado.

O artigo 33 da Lei 11.343/2006 engloba 18 (dezoito) verbos nucleares e não os individualiza, o que pode resultar numa aplicação desproporcional da pena prevista. No mesmo sentido, o artigo 28 da Lei 11.343/2006 prevê a situação subjetiva para tratamento de usuários. Diante disso, o estudo sugere que o tratamento objetivo para traficantes e usuários poderia amenizar a punição exacerbada, consequentemente refletindo no sistema penitenciário brasileiro.

A forma prevista atualmente na Lei possibilita a aplicação das penas do tráfico de drogas mesmo nos casos em que a pessoa portava algumas gramas de drogas e, somando as ditas circunstâncias analisadas pela autoridade, pode acarretar a segregação da pessoa autuada em estabelecimentos penais que representam o estado de coisa inconstitucional, como já reconhecido pelo STF. Esta situação é constatada nos inquéritos 114.4.2019.18800, 114.4.2019.19393, 114.4.2019.19373, 114.4.2019.18832, 114.4.2019.16741 e 114.4.2019.18436 em que a quantidade de drogas não ultrapassou cinquenta gramas.

Dado o exposto, pode-se concluir que a Lei de Drogas exerce papel simbólico na proteção à saúde pública, agravando outros problemas de ordem estrutural e maximizando a opressão estatal por meio do sistema de justiça criminal. 
ISSN n 2359-0106

Vol. 8, n. 2, 2021.

DOI 10.20873/uft.2359-0106.2021.v8n2.p526-556

\section{REFERÊNCIAS}

ALMEIDA, Silvio. Racismo Estrutural. São Paulo: Pólen, 2019.

ANDRADE, Vera Regina Pereira de. Por que a Criminologia (e qual Criminologia) é importante no Ensino Jurídico?. Unisul de Fato e de Direito: revista jurídica da Universidade do Sul de Santa Catarina, [S.I.], v. 3, n. 6, p. 179-183, jun. 2013. Disponível em:

http://www.portaldeperiodicos.unisul.br/index.php/U_Fato_Direito/article/view/1468/1 124. Acesso em: 12 fev. 2021

BARATTA, Alessandro. Criminologia crítica e crítica do direito penal: introdução à sociologia do direito penal. 3. ed. Rio de Janeiro: Revan, 2002. Tradução de Juarez Cirino dos Santos.

BECCARIA, Cesare. Dos Delitos e das Penas. S.L: Ridendo Castigat Mores, 1764.

BOITEUX, Luciana de Figueiredo Rodrigues. Controle Penal Sobre as Drogas Ilícitas: o impacto do proibicionismo no sistema penal e na sociedade. 2006. 273 f. Tese (Doutorado) - Curso de Direito, Universidade de São Paulo, São Paulo, 2006. Disponível em: https://cetadobserva.ufba.br/pt-br/publicacoes/controle-penal-sobredrogas-ilicitas-oimpacto-do-proibicionismo-no-sistema-penal-e-na. Acesso em: 26 out. 2020

BOITEUX, Luciana (org.). Tráfico e Constituição: um estudo sobre a atuação da justiça criminal do Rio de Janeiro e de Brasília no crime de tráfico de drogas.

Revista Jurídica da Presidência, Brasília, v. 11, n. 94, p. 1-29, jun. 2019.

Disponível em: https://revistajuridica.presidencia.gov.br/index.php/saj/issue/view/27. Acesso em: 14 fev. 2021.

BORGES, Juliana. O que é encarceramento em massa? Letramento: Belo Horizonte, 2018.

BRASIL. CONSELHO NACIONAL DE JUSTIÇA. Cadastro Nacional de Presos. 2018. Disponível em: https://www.cnj.jus.br/wp-content/uploads/2019/08/bnmp.pdf. Acesso em: 10 fev. 2021.

BRASIL. DEPARTAMENTO PENITENCIÁRIO NACIONAL. Levantamento de Informações Penitenciárias. 2019. Disponível em:

http://antigo.depen.gov.br/DEPEN/depen/sisdepen/infopen. Acesso em: 13 fev. 2021.

BRASIL. Lei no 11.343, de 23 de agosto de 2006. Brasil. Disponível em: http://www.planalto.gov.br/ccivil_03/_Ato2004-2006/2006/Lei/L11343.htm. Acesso em: 05 jan. 2021.

BRASIL. Portaria no 344, de 12 de maio de 1998. Brasil, Disponível em:

https://bvsms.saude.gov.br/bvs/saudelegis/svs/1998/prt0344_12_05_1998_rep.html. 
DOI 10.20873/uft.2359-0106.2021.v8n2.p526-556

Acesso em: 16 fev. 2021.

BRASIL. Supremo Tribunal Federal. Voto. Relator: Ministro Gilmar Mendes. Diário da Justiça Eletrônico. Brasília. Disponível em: https://www.conjur.com.br/dl/reposse-drogas-pra-consumo-voto-gilmar.pdf. Acesso em: 15 fev. 2021.

BUCHER, Richard; OLIVEIRA, Sandra RM. O discurso da "luta contra as drogas" e suas ideologias. Rev. Saúde Pública, São Paulo, v. 28, n. 2, pág. 137-145, abril de 1994. Disponível em http://www.scielo.br/scielo.php?script=sci_arttext\&pid=S0034$89101994000200008 \& \operatorname{lng}=e n \& n r m=i s o$. Acesso em 09 fev. 2021.

CARDOSO, RVP.; RAMOS, EMLS. Caracterização do crime de tráfico de drogas com base nas sentenças condenatórias da Justiça de Combate ao Crime Organizado em Belém-PA. Pesquisa, Sociedade e Desenvolvimento , [S. I.] , v. 9, n. 11, pág. e989119621, 2020. Disponível em:

https://rsdjournal.org/index.php/rsd/article/view/9621. Acesso em: 17 fev. 2021.

CARVALHO, Salo de. A Política Criminal de Drogas no Brasil: (do discurso oficial às razões da descriminalização). 1996. 365 f. Dissertação (Mestrado) - Curso de Direito, Universidade Federal de Santa Catarina, Florianópolis, 1996. Disponível em: https://repositorio.ufsc.br/handle/123456789/106430. Acesso em: 30 jan. 2021.

FARIA, Ana Amélia Cypreste; BARROS, Vanessa de Andrade. Tráfico de drogas: uma opção entre escolhas escassas. Psicologia \& Sociedade. Florianópolis, v. 23, n. 3, p. 536-544, Dec. 2011. Disponível em:

http://www.scielo.br/scielo.php?script=sci_arttext\&pid=S0102-

71822011000300011\&lng=en\&nrm=iso. Acesso em 02 Mar. 2021.

FARIAS, Ingrid Assunção. O que a guerra às drogas tem a ver com a morte de Agatha? 2019. Disponível em: https://www.justificando.com/2019/09/26/o-que-aguerra-as-drogas-tem-a-ver-com-a-morte-de-agatha/. Acesso em: 12 fev. 2021.

FERREIRA, Letícia C de M. NADAI, Larissa. Reflexões sobre burocracia e documentos: apresentação do Dossiê. CONFLUÊNCIAS | Revista Interdisciplinar de Sociologia e Direito. Vol. 12, n 3, pp. 07-13, 2015. Disponível em: https://periodicos.uff.br/confluencias/article/view/34498. Acesso em 27 out. 2020.

FOUCAULT, Michael. Vigiar e Punir: nascimento da prisão. 42. ed. Petrópolis/RJ: Vozes, 2014. 302 p. Tradução de Raquel Ramalhete.

FIORE, Maurício. O lugar do Estado na questão das drogas: o paradigma proibicionista e as alternativas. Novos estudos CEBRAP, São Paulo , n. 92, p. 921, 2012. Disponível em http://www.scielo.br/scielo.php?script=sci_arttext\&pid=S010133002012000100002\&lng=en\&nrm=iso. acesso em: 04 Fev. 2021.

FLAUZINA, Ana Luiza Pinheiro. Corpo negro caído no chão: o sistema penal e o projeto genocida do Estado brasileiro. 2006. 145 f. 2006. Dissertação (Mestrado em 
Direito) Universidade de Brasília, Brasília.

GUARTÁN, Juan Jiménez. MERCHAN, Marcia Fabre. Analisis de la política criminal dentro y fuera del estado de derecho: teoría, praxis y resultados. Espirales Revista Multidisciplinaria de investigación científica. Disponível em:

http://revistaespirales.com/index.php/es/article/view/255/215. Acesso em 03 fev. 2021.

KARAM, Maria Lúcia. Drogas: legislação brasileira e violações a direitos fundamentais. 2010. Disponível em: https://app.uff.br/slab/uploads/Drogaslegislacaobrasileira-LuciaKaram.doc. Acesso em 05 fev. 2021.

Maria Lucia. A Lei 11.343/06 e os repetidos danos do proibicionismo. In: LABATE, Beatriz Caiuby et al (org.). Drogas e cultura: novas perspectivas. Salvador: EDUFBA, 2008. p. 105-122.

MACRAE, Edward. O controle social do uso de substâncias psicoativas. In: PASSETTI, Edson; SILVA, Roberto B. Dias da (org.). Conversações abolicionistas: uma crítica do sistema penal e da sociedade punitiva. São Paulo: Instituto Brasileiro de Ciências Criminais, 1997. p. 107-116.

MALAGUTI BATISTA, Vera. Introdução crítica à criminologia brasileira. Rio de Janeiro: Revan, 2011.

MATO GROSSO. SECRETARIA DE ESTADO DE SEGURANÇA PÚBLICA. Centro Integrado de Comando e Controle da fronteira será instalado em Cáceres.

2018. Disponível em: http://www.sesp.mt.gov.br/-/centro-integrado-de-comando-econtrole-da-fronteira-sera-instalado-em-caceres. Acesso em: 23 fev. 2021.

MOORE, Michael. Illicit drugs -the political dilemma. Drug and Alcohol Review no 16, pp. 299-300, 1997. Disponível em: https://pubmed.ncbi.nlm.nih.gov/16203440/. Acesso em 08 fev. 2021.

$\mathrm{NUCCl}$, Guilherme de Souza. Leis penais e processuais penais comentadas. 13. ed. Rio de Janeiro: Forense, 2020.

OLMO, Rosa Del. A face oculta da droga. Rio de Janeiro: Revan, 1990.

PERDUCA, Marco. Vamos criminalizar a proibição! Avessos do prazer: drogas, Aids e direitos humanos. Disponível em: http://books.scielo.org/id/bgqvf . Acesso em: 05 fev. 2021.

REGINATO, Andréa Depieri de A.. Uma introdução à pesquisa documental. In: MACHADO, Maíra Rocha et al (org.). Pesquisar empiricamente o direito. São Paulo: Rede de Estudos Empíricos em Direito, 2017. p. 189-224.

REZENDE, Beatriz Vargas Ramos Gonçalves de. A ilusão do proibicionismo: estudo sobre a criminalização secundária do tráfico de drogas no Distrito Federal. 2011. 143 f. Tese (Doutorado) - Curso de Direito, Universidade de Brasília, Brasília, 
DOI 10.20873/uft.2359-0106.2021.v8n2.p526-556

2011. Disponível em: https://repositorio.unb.br/handle/10482/9856. Acesso em: 27 jul. 2021.

ROUSSEAU, Jean Jacques. Do contrato social. 3. ed. São Paulo: Martin Claret, 2011. Tradução de Pietro Nassetti.

SÃO PAULO. UNIVERSIDADE FEDERAL DE SÃO PAULO. DROGAS: um debate científico. 2016. Disponível em:

https://www.unifesp.br/reitoria/dci/images/DCl/revistas/Entreteses/Entreteses_06_20 16.pdf. Acesso em: 10 fev. 2021.

SHECAIRA, Sérgio Salomão. Criminologia: um estudo das escolas sociológicas. São Paulo: Estúdio Editores, 2014.

SOARES, M. K.; ZACKSESKI, C. M. Proibicionismo e poder regulatório: uma pesquisa documental sobre o processo administrativo de classificação das drogas. CADERNOS IBERO-AMERICANOS DE DIREITO SANITÁRIO, [S. I.], v. 5, n. 3, p. 135-156, 2016. Disponível em:

https://www.cadernos.prodisa.fiocruz.br/index.php/cadernos/article/view/306. Acesso em: 16 fev. 2021.

VALOIS, Luís Carlos. O Direito Penal da Guerra às Drogas. 2. ed. Belo Horizonte: D'Plácido, 2017.

VECHI, Fernando. Aquele que promove a venda do mal: traficantes como inimigos no município de Criciúma-SC. 2016. 73 f. TCC (Graduação) - Curso de Direito, Universidade do Extremo Sul Catarinense, Criciúma, 2016. Disponível em: http://repositorio.unesc.net/handle/1/5071. Acesso em: 30 jan. 2021.

VON LISZT, Franz. Direito Penal Allemão. Rio de Janeiro: F. Briguiet \& C., 1899. Tradução de José Hygino Duarte Pereira.

ZAFFARONI, Eugenio Raúl; BATISTA, Nilo. Direito Penal Brasileiro: teoria geral do direito penal. Rio de Janeiro: Revan, 2003. 